\title{
Menelisik Integritas Dan Profesionalisme Hakim Dalam Memutus Perkara \\ No.01/PID/TPK/2016/PT.DKI juncto Putusan Perkara \\ Nomor 67/Pid.Sus/TPK/2015/PN.JKT.PST Dari Perspektif Kode Etik Dan Pedoman Perilaku Hakim
}

\author{
Ridarson Galingging, S.H.,LL.M ${ }^{1}$ \\ Fakultas Hukum Universitas Yarsi \\ Email: ridarson@yahoo.com
}

\begin{abstract}
ABSTRAK
Tulisan ini akan menganalisis putusan hakim yang telah berkekuatan hukum tetap (incracht) dalam Putusan Perkara No.01/PID/TPK/2016/PT.DKI juncto Putusan Perkara No.67/Pid.Sus/TPK/2015/PN.JKT.PST. Analisis terhadap putusan pengadilan yang telah incracht dapat dilakukan dalam sistem hukum kita berdasarkan ketentuan dalam Ps.20 UU No.18 Th 2011 jo Ps.42 UU No.48 Th 2009. Penulis akan menunjukkan telah terjadinya pelanggaran, pengabaian dan ketidakkonsistenan hakim terhadap ketentuan Kode Etik dan Pedoman Perilaku Hakim, khususnya ketentuan tentang integritas dan profesionalisme hakim dalam menjalankan tugas dan fungsi yudisialnya untuk memeriksa dan mengadili setiap perkara yang dibawa kehadapannya.
\end{abstract}

Kata Kunci: Integritas, Profesionalisme Hakim, Kode Etik, Pedoman Perilaku Hakim

\begin{abstract}
This article will analyze the final and binding Jakarta High Court decision No.01/PID/TPK/2016/PT.DKI juncto Jakarta District Court decision No.67/Pid.Sus/TPK/2015/PN.JKT.PST. Conducting an analysis of a final and binding court decision can be carried out within the Indonesian legal system based on Article 20 Law No.18/2011 juncto Article 42 Law No.48/2009. The writer will demonstrate here that there exist violations, ignorance and inconsistencies of the judges handling the case with regard to the rules in the Indonesian Judges Code of Conduct and Judicial Ethics, especially on the articles concerning judge's integrity and professionalism in exercising its judicial function of adjudicating every case brought before him.
\end{abstract}

Keywords: integrity, judges professionalism, code of ethics, judicial code of conduct

\footnotetext{
${ }^{1}$ Praktisi Hukum di Jakarta dan Dosen Fakultas Hukum Universitas Yarsi
} 


\section{PENDAHULUAN}

Tujuan dari penulisan analisis terhadap Putusan Perkara No.01/PID/TPK/2016/PT.DKI juncto Putusan Perkara No.67/Pid.Sus/TPK/2015/PN.JKT.PSTini adalah untuk membuktikan dan menjelaskan bahwa putusan hakim dalam perkara ini diduga telah melangar atau boleh dikatakan tidak sejalan dengan prinsip integritas dan profesionalisme hakim seperti yang diatur didalam Kode Etik dan Pedoman Perilaku Hakim Indonesia (KE-PPH) yang telah dibentuk melalui Keputusan Bersama Mahkamah Agung RI dan Komisi Yudisial RI, Nomor 047/KMA/SKB/IV/2009 dan Nomor 02/SKB/P.KY/IV/2009 .

Disamping merupakan prinsip yang sudah menjadi ketentuan dari Kode Etik dan Pedoman Perilaku Hakim, tuntutan bahwa seorang hakim itu harus berintegritas tinggi dan berikap professional dalam menjalankan fungsinya sudah menjadi amanat konstitusi di negara kita seperti yang dituangkan di dalam PS 24 A ayat (2) UUD 45 yang berbunyi: "Hakim Agung harus memiliki integritas dan kepribadian yang tidak tercela, adil, professional, dan berpengalaman dibidang hukum." Lebih jauh lagi, agar integritas hakim ini betul-betul terjaga dan ditegakkan ditengah-tengah masyarakat, UUD 45 melalui PS 24 B(1) menugaskan Komisi Yudisial RI sebagai penjaga dan penegak kehormatan, keluhuran martabat, serta perilaku hakim.” Kewenangan Komisi Yudisial ini selanjutnya diatur dalam Pasal 40 (2) UU No.48 Tahun 2009 Tentang Kekuasaan Kehakiman yang menentukan bahwa pengawasan yang dilakukan oleh Komisi Yudisial tersebut dilakukan berdasarkan Kode Etik dan Pedoman Perilaku Hakim seperti yang tersebut diatas.

Salah satu cara untuk melihat dan mengetahui apakah prinsip dan ketentuan yang telah diatur oleh Kode Etik dan Pedoman Perilaku Hakim, ketentuan serta norma konstitusi ini benar-benar ada dan telah diterapkan serta tidak dilanggar atau diabaikan oleh hakim dalam menjalankan tugas dan fungsi yudisialnya mengadili dan memutus perkara yang dibawa kehadapannya adalah melalui analisis terhadap putusan hakim itu sendiri. Hal ini sejalan dengan apa yang tertuang dalam Pembukaan Kode Etik dan Pedoman Perilaku Hakim bahwa, "kehormatan hakim itu terutama terlihat pada putusan yang dibuatnya, dan 
pertimbangan yang melandasi, atau keseluruhan proses pengambilan putusan yang bukan saja berlandaskan peraturan perundang-undangan, tetapi juga rasa keadilan dan kearifan yang timbul dari masyarakat."

Analisis terhadap putusan pengadilan yang telah incracht ini memang dapat pula dilakukan dalam kerangka sistem hukum kita seperti yang ditentukan oleh Pasal 42 UU Nomor 48 Tahun 2009 Tentang Kekuasaan Kehakiman. Jadi analisis terhadap putusan hakim yang telah berkekuatan tetap (incracht) dalam Putusan Perkara No.01/PID/TPK/2016/PT.DKI juncto Putusan Perkara No.67/Pid.Sus/TPK/2015/PN.JKT.PST bisa dilakukan dan secara yuridis dimungkinkan pula dilakukan berdasarkan Ps 20 UU No.18 Th 2011 jo Ps 42 UU No.48 Th 2009. Inilah alasan dan dasar mengapa penulis melakukan analisis atas putusan hakim dalam perkara Barnabas Suebu ini.

$\begin{array}{ccccc}\text { Dengan dilakukannya } & \text { analisis } & \text { terhadap } & \text { Putusan } & \text { Perkara } \\ \text { No.01/PID/TPK/2016/PT.DKI } & \text { juncto } & \text { Putusan } & \text { Perkara }\end{array}$

No.67/Pid.Sus/TPK/2015/PN.JKT.PST ini diharapkan akan ditemukan adanya pelanggaran, pengabaian dan ketidakkonsitensian hakim terhadap ketentuan Kode Etik dan Pedoman Perilaku Hakim, khususnya ketentuan tentang integritas dan profesionalisme hakim dalam menjalankan tugas dan fungsi yudisialnya untuk memeriksa dan mengadili setiap perkara yang dibawa kehadapannya.

\section{PEMBAHASAN}

\section{A.Konsep Integritas Dan Profesionalisme Hakim}

Pekerjaan hakim adalah pekerjaan sebuah profesi. Ada etika profesi yang harus diikuti dalam menjalankan fungsi hakim tersebut. Etika profesi hakim tersebut akan menjadi dasar dalam menilai profesionalisme seorang hakim. Etika profesi hakim tersebut kalau dilanggar atau tidak diikuti maka hakim tersebut dapat dikategorikan telah melanggar etika profesi atau pedoman perilaku hakim dan dapat dikenakan sanksi oleh lembaga yang berwenang menegakkan etika profesi hakim tersebut. Salah satu prinsip penting dalam perilaku hakim, baik dalam kehidupan pribadi maupun dalam menjalankan tugas profesionalnya yang diatur dalam etika profesi hakim itu adalah prinsip integritas. 
Kalau kita berbicara dan membahas persoalan integritas hakim maka rujukan yang secara universal diterima sebagai referensi adalah The Bangalore Principles of Judicial Conduct (BPJC) yang secara resmi diadopsi pada November 2002. ${ }^{2}$ BPJC ini dirancang sebagai kode etik atau pedoman perilaku hakim dalam menjalankan fungsi sebagai seorang hakim. Prinsip-Prinsip dalam BPJC ini telah diterima oleh lembaga-lembaga peradilan di berbagai negara dan organisasi-organisasi internasional terkait dengan integritas hakim dan proses peradilan, seperti pengakuan yang diberikan oleh the American Bar Association (ABA) dan the International Commission of Jurists. "The Bangalore Principles of Judicial Conduct have increasingly been accepted by the different sectors of the global judiciary and by international agencies interested in the integrity of the judicial process. ${ }^{3}$ Bahkan jurisprudensi Pengadilan HAM Eropa pun telah membahas pula persoalan integritas hakim ini dalam putusan-putusannya. ${ }^{4}$

Perserikatan Bangsa Bangsa (PBB) pun telah ikut pula memperkuat legitimasi dan posisi BPJC ini secara internasional melalui Resolusi 2006/23 tanggal 27 Juli 2006 Dewan Ekonomi dan Sosial Perserikatan Bangsa-Bangsa (The United Nations Social and Economic Councils). PBB menyerukan kepada negara negara anggotanya untuk memasukkan prinsip_prinsip yang terkandung dalam the Bangalore Principles of Judicial Coduct tersebut kedalam peranturan perundang-undangan negara anggota PBB ketika menyusun atau mengembangkan ketentuan-ketentuan yang terkait dengan perilaku etis dan professional lembagalembaga peradilan masing-masing negara. Selain Dewan Ekonomi dan Sosial PBB, Badan PBB yang bergerak dibidang Obat-Obatan Terlarang dan Kejahatan (The United Nations Office on Drugs and Crime, UNODC) juga aktif sekali mendukung the Bangalore Principles of Judicial Conduct ini ${ }^{5}$. Tidak hanya pada tataran internasional, di Indonesia sendiri Mahkamah Agung dan Komisi Judisial juga telah membahas secara mendalam dan mempertimbangkan the Bangalore

2 D.Brian Dennison and Pamela T. Kalyegira, Legal Ethics and Professionalism: A Handbook for Uganda, Globethics.net International Secretariat, Geneva, 2014, 2014,hlm. 296, www.globethics.net, diakses 7 Maret 2019

${ }^{3}$ United Nations Office on Drugs and Crime, Commentary on the Bangalore Principles of Judicial Conduct, UNODC, 2007, hlm.5

${ }^{4}$ Jonathan Soeharno, Is Judicial Integrity a Norm? An Inquiry into the Concept of Judicial Integrity in England and the Netherlands, Utrecht Law Review, Volume 3, Issue 1 (June), 2007 Hlm. 13

${ }^{5}$ United Nations Office on Drugs and Crime, Ibid, hlm.5 
Principles of Judicial Conduct ini dalam penyusunan Kode Etik dan Pedoman Perilaku Hakim Indonesia. ${ }^{6}$

BPJC ini mengatur tentang prinsip-prinsip yang harus dijadikan pedoman perilaku dan bertindak para hakim dalam menjalankan fungsi mereka dipersidangan dan dalam kehidupan sehari-hari para hakim. Adapun prinsipprinsip yang diatur dalam BPJC tersebut adalah prinsip: Independen (independence), Imparsial ( impartiality), Integritas (integrity), Kepatutan (propriety), Persamaan (equality), Kompetensi (competence) dan Kerajinan (diligence). ${ }^{7}$ Keenam prinsip-prinsip tersebut merupakan satu kesatuan yang tidak dapat dipisah-pisahkan anatara yang satu dengan yang lainnya dalam kehidupan professional dan kehidupan pribadi seorang hakim. Bagaimana dengan posisi prinsip integritas (integrity) diantara prinsip-prinsip yang lainnya? Prinsip integritas tidak bisa diabaikan. Penting sekali keberadaan prinsip integritas ini. Jika tidak memiliki integritas maka jangan berharap bahwa seorang hakim itu akan bisa bersikap independen dan imparsial dalam melakukan fungsinya sebagai hakim di persidangan. Hanya hakim yang berintegritas sajalah yang akan bisa bersikap independen dan imparsial. Begitu juga dalam kaitannya dengan prinsip equality. Hanya hakim yang berintegritas sajalah yang bisa menerapkan prinsip equality dan tidak bersikap bias dan diskriminatif.

Bagaimana pula sebenarnya penjabaran dan ruang lingkup dari prinsip integritas ini sebagai sebuah konsep didalam the Bangalore Principles of Judicial Conduct ? Kutipan dari Komentar atas the Bangalore Principles of Judicial Conduct yang diterbitkan UNODC dibawah ini dapat menggambarkan dan menjelaskan ruang lingkup dari konsep "integrity" itu:

"Integrity is the attribute of rectitude and righteousness. The components of integrity are honesty and judicial morality. A judge should always, not only in the discharge of official duties, act honourably and in a manner befitting the judicial office; be free from fraud, deceit and falsehood; and be good

${ }^{6}$ Keputusan Bersama Ketua Mahkamah Agung RI Nomor:047/KMA/SKB/IV/2009 dan KomisiYudisialNomor: 02/SKB/P.KY/IV/2009 Tentang Kode Etik Dan Pedoman Perilaku Hakim.

${ }^{7}$ United Nations Office on Drugs and Crime, op.cit, hlm.3 
and virtuous in behavior and in character. There are no degrees of integrity as so defined. Integrity is absolute. In the judiciary, integrity is more than a virtue; it is a necessity. "8

Kutipan tersebut diatas penulis terjemahkan sebagai berikut:

"Integritas itu terkait dengan kebajikan dan kebenaran atau keadilan. Komponen dari integritas itu adalah kejujuran dan moralitas dalam menjalankan tugas-tugas hakim. Seorang hakim haruslah selalu, tidak hanya dalam menjalankan kewajibankewajibannya, bertindak terhormat dan berperilaku yang sesuai dengan profesi hakim; terbebas dari kecurangan, penipuan, dan kepalsuan; berperilaku baik dan berkarakter baik pula. Integritas itu tidak memiliki derajad atau tingkatan. Intergritas itu bersifat absolut. Di lembaga peradilan, integritas itu lebih dari sekedar kebaikan, ia merupakan suatu kebutuhan."

Kode Etik dan Pedoman Perilaku Hakim Indonesia menggunakan istilah "berintegritas tinggi" yang "bermakna sikap dan kepribadian yang utuh, berwibawa, jujur dan tidak tergoyahkan. Integritas tingggi pada hakekatnya terwujud pada sikap setia dan tangguh berpegang pada nilai-nilai atau normanorma yang berlaku dalam melaksanakan tugas."9 "Integrity is the principle of consistently behaving in accordance with ethical values." 10

Bagaimana pula dengan penjabaran dan ruang lingkup dari konsep profesionalisme? Apa sajakah yang merupakan elemen-elemen yang harus ada? Neil Hamilton dalam tulisannya "Profesionalism Clearly Defined" yang diterbitkan oleh The American Bar Association menyatakan bahwa:

"Profesionalism is a much broader concept than legal ethics...professionalism includes not only civility among members of the bench and bar, but also competence, integrity, respect for the rule of law, participation in pro bono and

\footnotetext{
${ }^{8}$ United Nations Office on Drugs and Crime, $I d$, hlm.79

${ }^{9}$ Keputusan Bersama Ketua Mahkamah Agung RI Dan Ketua Komisi Yudisial RI Nomor 047/KMA/SKB/IV/2009 dan 02/SKB/P.KY/IV/2009 Tentang Kode Etik Dan Pedoman Perilaku Hakim, prinsip ke 5

10 DCAF, Training Manual on Police integrity, Geneva, 2015 hlm.24 ada di https://www.dcaf.ch/ diakses 31 Maret 2019
} 
community service, and conduct by members of the legal profession that exceeds minimum ethical requirements. Ethics rules are what a lawyer must obey. Principles of professionalism are what a lawyer should live by in conducting his or her affairs." 11

Konsep profesionalisme yang dikemukakan oleh Neil Hamilton tersebut diatas penulis terjemahkan seperti yang tertulis dibawah ini:

"Profesionalisme itu adalah sebuah konsep yang jauh lebih luas dari etika profesi hukum...profesionalisme termasuk tidak hanya sopan dalam berperilaku diantara anggota organisasi hakim dan pengacara, tetapi juga termasuk kompetensi, integritas, penghormatan terhadap hukum, partisiapsi dalam memberikan bantuan hukum secara cuma-cuma kepada orang yang tidak mampu dan perilaku yang melebihi persyaratan minimal yang diatur oleh etika profesi. Ketentuan-ketentuan etika adalah sesuatu yang harus ditaati seorang pengacara. Prinsip-prinsip profesionalisme adalah sesuatu yang ada dalam hidup seorang pengacara dalam ia melakukan urusanurusannya."

Dalam Kode Etik dan Pedoman Perilaku Hakim Indonesia, untuk menggambarkan profesionalisme digunakan istilah "bersikap professional yang bermakna suatu sikap moral yang dilandasi oleh tekad untuk melaksanakan pekerjaan yang dipilihnya dengan kesungguhan, yang didukung oleh keahlian atas dasar pengetahuan, keterampilan dan wawasan luas." Selanjutnya dikatakan pula bahwa "sikap professional akan mendorong terbentuknya pribadi yang senantiasa menjaga dan mempertahankan mutu pekerjaan, serta berusaha untuk meningkatkan pengetahuan dan kinerja, sehingga tercapai setinggi-tingginya mutu hasil pekerjaan, efektif dan efisien." 12

\footnotetext{
${ }^{11}$ Neil Hamilton, Professionalism Clearly Defined, op.cit, hlm.7

${ }^{12}$ Keputusan Bersama Ketua Mahkamah Agung RI Dan Ketua Komisi Yudisial RI Nomor 047/KMA/SKB/IV/2009 dan 02/SKB/P.KY/IV/2009 Tentang Kode Etik Dan Pedoman Perilaku Hakim, prinsip ke 10
} 
Komponen-komponen dari prinsip integritas dan professionalism hakim seperti yang tersebut dalam the Bangalore Principles of Judicial Conduct dan Kode Etik dan Pedoman Perilaku Hakim Indonesia tersebut diatas akan menjadi tolak ukur untuk menilai sejauhmana seorang hakim itu dapat dikategorikan sebagai hakim yang berintegritas dan professional dalam menjalankan proses persidangan dimuka pengadilan dan dalam membuat putusan atas suatu kasus yang dihadapinya. Jadi faktor integritas dan profesionalisme hakim ini merupakan suatu komponen yang penting sekali dalam melakukan penilaian terhadap perilaku etis seorang hakim dalam menjalankan tugas dan fungsi yudisialnya.

\section{B.Integritas Dan Profesionalisme Hakim Indonesia}

Sangatlah sulit untuk mengatakan bahwa integritas dan profesionalisme hakim di Indonesia itu baik-baik saja dan tidak sedang menghadapi masalah yang sangat serius pada saat ini. Citra lembaga peradilan dan hakim Indonesia tidak bisa dibilang positif dimata masyarakat baik domestik maupun dimata dunia internasional. Laporan-laporan yang diterbitkan oleh berbagai lembaga internasional dan nasional yang aktif memonitor perkembangan hukum dan dunia peradilan di Indonesia masih banyak menunjukkan bahwa dunia hukum dan peradilan kita masih belumlah terbebas dari praktek-praktek korupsi diberbagai lini bidang kehidupan. Hakim-hakim dan petugas-petugas lembaga peradilan masih sering menerima suap jika anggota masyarakat berurusan dengan mereka.

Ombudsman RI telah menerima 392 komplein terkait maladminstrasi putusan-putusan pengadilan diantara tahun 2016 dan Mei 2017, sedangkan Komisi Yudisial (KY) telah pula menerima 712 komplein masyarakat terkait dengan perilaku tidak patut pejabat pengadilan (judicial misconduct) dan merekomendasikan agar 33 hakim diselidiki lebih jauh. ${ }^{13}$ Sementara itu, berdasarkan catatan Indonesian Corruption Watch (ICW) setidak-tidaknya terdapat 18 hakim dan 10 aparat pengadilan non-hakim yang ditangkap KPK dalam periode Maret 2012 hingga November 2018. Sebagian besar terjerat OTT

${ }^{13}$ US Department of State, Indonesia 2017 Human Rights Report, https://www.state.gove/ diakses 12 Maret 2019 
KPK. ${ }^{14}$ Transparency International (TI) dalam laporannya yang diterbitkan 18 Oktober 2018 menyatakan bahwa korupsi di lingkungan lembaga peradilan Indonesia itu masih merupakan masalah serius. Berikut bunyi pernyataan dari Tranparency Internasional tersebut:"Corruption in the judiciary is of serious concern, while political interference plays only a minor role in the judiciary, bribery influences judicial procedures at every level. High ranking judges have frequently been arrested for corruption ..." 15

Hal yang sangat memprihatinkan sekali dan kelihatannya tidak muncul menjadi pemberitaan dan perbincangan publik, dilembaga peradilan kita masih sering dijumpai praktek-praktek seperti yang diungkapkan oleh mantan Komisioner Komisi Yudisial Suparman Marzuki dibawah ini:

a.Memperlambat atau mempercepat mengunggah putusan ke direktori putusan Mahkamah Agung;termasuk mempercepat atau memperlambat penyampaian Salinan putusan ke terpidana, jaksa, penggugat atau tergugat;

b.Menahan permohonan kasasi jaksa agar proses kasasi berlarut-larut. Bahkan yang pernah penulis sampaikan langsung ke pimpinan Mahkamah Agung, berkas kasasi jaksa ditahan, dengan permintaan tidak dikirim ke kamar pidana sampai Atidjo Alkostar pensiun;

c.Membocorkan putusan kasasi atau PK kepada terpidana yang tidak ditahan atau kepada penasehat hukum sebelum secara resmi putusan disampaikan sehingga terpidana yang berniat menghindari eksekusi punya kesempatan melarikan diri ;

d.Menahan atau melambat-lambatkan penyerahan ekstrak vonis kepada jaksa, seperti dalam kasus Sudjiono Timan sehingga terpidana kabur;

e.Menahan putusan kasasi yang menguatkan atau meningkatkan vonis supaya tidak buru-buru disampaikan kepengadilan dan jaksa penuntut umum agar eksekusi tertunda, dan dalam penundaan eksekusi itu terpidana bisa melakukan sesuatu;

14 Kompas, Dalam Enam Tahun 28 Aparat Lembaga Peradilan Ditangkap KPK, https://nasional.kompas.com, 30 November 2018 diakses 10 Maret 2019

15 Transparency International, Indonesia: Overview of Corruption and Anti-Corruption, 18 October 2018 
f.Menghubungi pihak-pihak untuk merundingkan proses dan atau putusan kasasi atau PK yang diajukan. Untuk meyakinkan, oknum pelaku biasanya menyebutnyebut hakim agung;

g.Dalam perkara perdata, oknum pegawai Mahkamah Agung menahan kasasi atau PK sehingga pihak yang dikalahkan punya waktu melakukan sesuatu terhadap objek sengketa, misalnya meneruskan mengeksploitasi tambang, memetik hasil panen, menahan proses jual beli yang tinggal menunggu Salinan resmi putusan harus dipastikan berhenti. ${ }^{16}$

Kondisi buruknya integritas dan profesionalisme hakim di Indonesia seperti yang telah penulis gambarkan dengan banyaknya komplein kepada Ombudsman, Komisi Yudisial dan penangkapan-penangkapan terhadap hakim dan apparat pengadilan oleh Komisi Pemberantasan Korupsi (KPK) diatas tentu saja menjadi tantangan serius dan merupakan permasalahan besar yang harus segera diatasi oleh Mahkamaha Agung sebagai lembaga tertinggi dibidang peradilan yang menjadi wadah bagi para hakim di Indonesia. Memang MA telah membentuk Peraturan MA Nomor 8 Tahun 2016 Tentang Pengawasan dan Pembinaan Atasan Langsung di lingkungan Mahkamah Agung dan Badan Peradilan di bawahnya, tetapi tampaknya peraturan MA ini belumlah efektif dalam mengawasi hakim dan petugas pengadilan. Berdasarkan Perma tersebut, ketua pengadilan dibebani tanggung jawab untuk melakukan pengawasan terhadap bawahan, tetapi sering terjadi justru ketua pengadilan yang melakukan pelanggaran dan menerima suap. ${ }^{17}$

Tidak hanya Mahkamah Agung yang telah berupaya untuk memperbaiki integritas dan profesionalisme hakim ini, Lembaga Komisi Yudisial yang baru dibentuk pada tahun 2005 juga turut membantu merealisasikan terwujudnya hakim yang berintegritas dan profesional ${ }^{18}$ yang juga merupakan kehendak dari konstitusi kita seperti yang tertuang dalam ketentuan Pasal 24A ayat (2) UUD 45

${ }^{16}$ Suparman Marzuki, Mencetak Hakim Berintegritas, Dalam Optimalisasi Wewenang KY dalam Mewujudkan Hakim Berintegritas, Sekretariat Jenderal KY, Jakarta 2016 hlm.92

${ }^{17}$ Kompas ICW: Dalam Enam Tahun, 28 Aparat Lembaga Peradilan Ditangkap KPK, 30 November 2018, https://nasional.kompas.com diakses 31 Maret 2019

${ }_{18}$ Pasal 20 (2) UU No.18 Tahun 2011 Tentang Perubahan atas UU No. 22 Tahun 2004 Tentang Komisi Yudisial menentukan bahwa Komisi Yudisial mempunyai tugas untuk mengupayakan peningkatan kapasitas dan kesejahteraan hakim selain tugas menjaga dan menegakkan kehormatan, keluhuran martabat, serta perilaku hakim. 
yang menyatakan bahwa "Hakim Agung harus memiliki integritas dan kepribadian tidak tercela, adil, professional, dan berpengalaman dibidang hukum.” Komisi Yudisial melalui Pasal 24B (1) UUD 45 diberi kewenangan untuk mengusulkan pengangkatan Hakim Agung dan wewenang lain dalam rangka menjaga dan menegakkan kehormatan, keluhuran martabat, serta perilaku hakim". Kewenangan menegakkan ini diartikan sebagai kewenangan melakukan pengawasan.

Kewenangan pengawasan yang dimiliki oleh Komisi Yudisial berdasarkan Pasal 24B (1) konstitusi tersebut diimplemetasikan lagi kedalam Pasal 40 UU Nomor 48 Tahun 2009 tentang Kekuasaan Kehakiman, yang menentukan baahwa: "Dalam rangka menjaga dan menegakkan kehormatan, keluhuran martabat, serta perilaku hakim dilakukan pengawasan eksternal oleh Komisi Yudisial. Pengawasan tersebut dilakukan berdasarkan Kode Etik dan Pedoman Perilaku Hakim (Pasal 40 ayat (2) UU Nomor 48 Tahun 2009). Makna dari ketentuan tersebut dapat pula dilihat dalam Pasal 13A ayat (2) UU Nomor 49 Tahun 2009, Pasal 12 A ayat (2) UU Nomor 50 Tahun 2009 tentang Perubahan Kedua atas UU Peradilan Agama, Pasal 13 A ayat (2) UU Nomor 51 Tahun 2009, tentang Perubahan Peradilan TUN. ${ }^{19}$

Kemudian, untuk implementasi lebih kongkrit lagi dari kewenangan untuk menjaga dan menegakkan kehormatan, keluhuran martabat serta perilaku hakim itu dirumuskan pula suatu ketentuan yang menyatakan bahwa Komisi Yudisial dapat melakukan eksaminasi terhadap putusan yang telah incracht sebagai dasar untuk melakukan mutasi hakim. Hal tersebut tercermin dalam Pasal 42 UU Nomor 48 Tahun 2009 Tentang Kekuasaan Kehakiman yang mengatur bahwa: "Dalam rangka menjaga dan menegakkan kehormatan, keluhuran martabat, serta perilaku hakim , Komisi Yudisial dapat menganalisis putusan pengadilan yang telah memperoleh kekuatan hukum tetap sebagai dasar rekomendasi untuk melakukan mutasi hakim." 20

19 Jaja Ahmad Jayus, Pelaksanaan Pengawasan Komisi Yudisial antara Etika dan Teknis Yudisial, Dalam Optimalisasi Wewenang KY dalam Mewujudkan Hakim Berintegritas, Sekretariat Jenderal KY, Jakarta 2016 hlm.64

${ }^{20}$ Jaja Ahamad Jayus, Ibid, hlm 64 
Ketentuan Pasal 42 UU Nomor: 48 Tahun 2009 tersebut diatas menempatkan putusan hakim sebagai dasar untuk melakukan mutasi hakim di Indonesia. Baik buruknya performance atau kinerja seseorang sebagai hakim itu ditentukan oleh kualitas putusan kasus-kasus yang telah dibuatnya. Bagi hakimhakim yang kualitas putusannya dinilai buruk maka dia dapat dimutasi. Menurut Pasal 42 tersebut Komisi Yudisial yang melakukan analisis. Setelah analisis putusan yang sudah berkekuatan tetap tersebut dilakukan maka hasil analisis tersebut akan dijadikan dasar bagi Komisi Yudisial untuk merekomendasilan mutasi hakim tersebut kepada Mahkamah Agung.

Demikianlah pesan yang disampaikan oleh Pasal 42 UU No.48 Tahun 2009 Tentang Kekuasaan Kehakiman. Jadi kedudukan putusan hakim itu penting sekali dalam rangka untuk peningkatan karir seorang hakim. Hakim yang sering membuat putusan-putusan yang bagus dan bisa dipertanggungjawabkan secara keilmuan maka karirnya akan cemerlang. Akan tetapi sebaliknya, hakim-hakim yang sering membuat putusan-putusan yang kontraversial, melanggar Hukum Acara yang menjadi panduan hakim dalam memeriksa dan memutus perkara dan membuat kegaduhan didalam masyarakat akan terhambat karirnya. Jadi ada korelasi antara kualitas putusan yang dibuat seorang hakim dengan dengan peningkatan karirnya.

Tetapi dalam pelaksanaan ketentuan Pasal 42 UU No. 48 Tahun 2009 tersebut Komisi Yudisial sering menghadapi gesekan dengan Mahkamah Agung. Gesekan itu terjadi jika Komisi Yudisial hendak menyelidiki suatu putusan hakim yang diduga bermasalah terkait dengan pelanggaran atas ketentuan Hukum Acara yang dituduhkan kepada hakim yang membuat putusan tersebut. Komisi Yudisial menganggap ada sisi yang masih termasuk pelanggaran KEPPH terkait dengan suatu pelanggaran Hukum Acara dengan sikap tidak profesionalnya seorang hakim, sementara itu Mahkamah Agung menganggap hal tersebut merupakan murni ranah teknis yudisial semata yang bukan termasuk kewenangan Komisi Yudisial untuk memeriksanya.

Perbedaan pandangan tentang apakah hal tersebut merupakan pelanggaran $\mathrm{KEPPH}$ atau termasuk persoalan teknis yudisial sampai saat ini belum pernah tuntas penyelesaiannya, walaupun dalam Panduan Penegakan Kode Etik dan 
Pedoman Perilaku Hakim, yaitu Peraturan Bersama No.02/PB MA/IX/2012 dan No.02/PB/P.KY/09/2012 dalam Pasal 17 dikatakan bahwa "Dalam hal Komisi Yudisial menerima laporan dugaan pelanggaran kode etik yang juga merupakan pelanggaran hukum acara, Komisi Yudisial dapat mengusulkan kepada Mahkamah Agung untuk ditindaklanjuti." Penulis sendiri berpendapat walaupun itu merupakan persoalan teknis yudisial, kalau pelanggaran atas Hukum Acara tersebut disebabkan oleh karena rendahnya tingkat pemahaman dan pengetahuan hukum dari hakim yang bersangkutan, maka hal tersebut mencerminkan rendahnya profesionalisme hakim yang bersangkutan. Persoalan rendahnya tingkat profesionalisme hakim ini masih menjadi ranah KEPPH dan sekaligus juga merupakan persoalan teknis yudisial. Kedua lembaga ini, baik Komisi Yudisial maupun Mahkamah Agung bisa menanganinya, cuman dengan pendekatan yang berbeda. Komsi Yudisial bisa menyelidiki dari aspek profesionalismenya, sedangkan Mahkamah Agung dapat menyelidiki dari aspek teknis yudisialnya. Jadi tidak ada yang perlu dipertentangkan sebenarnya.

Kelihatannya upaya upaya untuk meningkatkan integritas dan profesionalisme hakim ini memang merupakan pekerjaan jangka panjang yang harus dilakukan secara konsisten dan terus menerus, tanpa henti-hentinya. Untuk bisa memiliki hakim yang berintegritas tinggi dan professional seperti yang dimiliki oleh banyak negara-negara demokrasi modern yang sudah mapan merupakan tantangan tersendiri bagi pemerintah, DPR, Mahkamah Agung dan Komisi Yudisial. 


\section{C.Integritas Dan Profesionalisme Hakim Dalam Putusan Pengadilan Tinggi Jakarta Nomor: 01/Pid.Sus/TPK/2016/PT.DKI Jo Putusan Pengadilan Tindak Pidana Korupsi Pada Pengadilan Negeri Jakarta Pusat Nomor: 67/Pid.Sus/TPK/2015/PN.Jkt.Pst.}

Hakim Pengadilan Tinggi Jakarta telah melakukan pelanggaran dalam memutus perkara Nomor: 01/Pid.Sus/TPK/2016/PT.DKI Jo Putusan Pengadilan Tindak Pidana Korupsi Pada Pengadilan Negeri Jakarta Pusat Nomor: 67/Pid.Sus/TPK/2015/PN.Jkt.Pst. Pelanggaran yang telah dilakukan oleh hakim dalam perkara atas nama Barnabas Suebu ini dapat dikategorikan sebagai pelanggaran terhadap Kode Etik dan Pedoman Perilaku Hakim sebagaimana yang telah menjadi keputusan Bersama Ketua Mahkamah Agung RI Nomor: 047/KMA/SKB/IV/2009 dan Ketua Komisi Yudisial RI Nomor: 02/SKB/P.KY/IV/2009 tentang Kode Etik Dan Pedoman Perilaku Hakim.

Adapun pelanggaran yang telah dilakukan oleh hakim PT.DKI pemeriksa perkara ini berkaitan dengan pelanggaran terhadap prinsip-prinsip dasar Kode Etik dan Pedoman Perilaku Hakim aturan ke (5) perihal berintegritas tinggi dan aturan ke (10) perihal bersikap professional. Prinsip bahwa hakim itu harus berintegritas tinggi dan bersikap professional merupakan prinsip yang tidak dapat ditawartawar lagi keberadaannya dan tidak dimiliki oleh hakim PT.DKI yang memeriksa dan mengadili perkara ini dalam menjatuhkan putusannya. Ada beberapa hal yang menjadi dasar pertimbangan bagi penulis untuk menyimpulkan bahwa prinsip berintegritas tinggi dan bersikap professional sama sekali tidak ditunjukkan oleh hakim PT.DKI dalam memeriksa dan memutus perkara Barnabas Suebu ini.

Prinsip berintegritas tinggi itu mengharuskan seorang hakim berpegang kepada nilai-nilai atau norma-norma yang berlaku dalam melaksanakan tugas dan fungsi judisialnya. Sedangkan prinsip bersikap professional mengharuskan seorang hakim bekerja dengan dasar keahlian, ilmu pengetahuan dan ketrampilan. Bersikap professional tersebut juga mewajibkan seorang hakim untuk berusaha semaksimal mungkin menghindari terjadinya kekeliruan dalam membuat keputusannya. Pelanggaran yang terjadi dalam membuat putusan dalam perkara Nomor: 01/Pid.Sus/TPK/2016/PT.DKI Jo Putusan Pengadilan Tindak Pidana Korupsi Pada Pengadilan Negeri Jakarta Pusat Nomor: 
67/Pid.Sus/TPK/2015/PN.Jkt.Pst. telah penulis kelompokkan dalam dua bagian, yaitu pelanggaran yang terkait dengan bidang Hukum Acara Pidana (KUHAP), dan kekeliruan terkait dengan penerapan pasal yang didakwakan.

Semua pelanggaran dan kekeliruan tersebut semestinya tidak akan terjadi kalau hakim PT.DKI yang memeriksa dan mengadili perkara ini benar-benar bersikap professional dalam melakukan fungsi judisialnya sebagai hakim. Profesionalisme dalam Kode Etik dan Pedoman Perilaku Hakim itu menentukan bahwa hakim itu bekerja dengan dasar keahlian dan ilmu pengetahuan. Tetapi dalam memutus perkara atas nama Barnabas Suebu ini hakim pemeriksa telah melanggar PS 197 (1) KUHAP terkait dengan syarat formal putusan, serta tidak dapat membuktikan unsur-unsur PS 3 UU TPK, PS 55 dan 65 KUHP. Lebih jauh lagi, juga terjadi pelanggaran terhadap PS 185 (6) KUHAP terkait dengan saksi yang harus benar-benar bebas, jujur dan obyektif yang tidak tampak dalam pertimbangan hukum hakim.

Penulis sependapat dengan apa yang telah disampaikan oleh Majelis Eksaminasi Asosiasi Pimpinan Perguruan Tinggi Hukum Indonesia (APPTHI) dalam Pendapat Hukum/Legal Opinion yang telah dibuat atas perkara Nomor: 01/Pid.Sus/TPK/2016/PT.DKI Jo Putusan Pengadilan Tindak Pidana Korupsi Pada Pengadilan Negeri Jakarta Pusat Nomor: 67/Pid.Sus/TPK/2015/PN.Jkt.Pst yang mengatakan bahwa kekeliruan telah terjadi pada pemberatan sanksi pidana yang tidak rasional yang semula pidana penjara 4 tahun 6 bulan menjadi 8 tahun pidana penjara. Begitu juga dengan pencabutan hak memilih dan dipilih yang telah dijatuhkan dengan pertimbangan yang begitu sumir sekali. Yang lebih memprihatinkan lagi, hakim PT DKI yang memeriksa perkara Barnabas Suebu ini telah mengambil alih begitu saja keseluruhan kesimpulan Pengadilan Negeri tanpa mempertimbangkan lebih dalam lagi substansi perkara tersebut. ${ }^{21}$

Pelanggaran dan kekeliruan hukum tersebut seharusnya tidak boleh dilakukan oleh hakim Pengadilan Tinggi Jakarta yang sebenarnya berfungsi sebagai forum judisial untuk mengoreksi secara total kekeliruan-kekeliruan

${ }^{21}$ Majelis Eksaminasi Asosiasi Pimpinan Perguruan Tinggi Hukum Indonesia (APPTHI), Pendapat Hukum/Legal Opinion Perkara Tindak Pidana Korupsi Atas Nama Barnabas Suebu Pada Putusan Pengadilan Negeri No.67/PID.Sus/TPK/2015/PN.JKT.PST Juncto Putusan Pengadilan Tinggi No.01/PID/TPK/2016/PT.DKI, Jakarta, Desember 2017 hlm 7-8 
hukum (legal error) yang telah dibuat oleh hakim dalam putusan Pengadilan Negeri Jakarta Pusat. Yang menjadi pertanyaan selanjutnya untuk diselidiki secara langsung dan mendalam lagi oleh Komisi Yudisial apakah kekeliruan itu telah dengan sengaja dibuat atau memang karena kekhilafan biasa saja?

\section{PENUTUP}

Berdasarkan ulasan yang telah penulis paparkan diatas, dapatlah disimpulkan bahwa Putusan Pengadilan Tinggi DKI Nomor: 01/Pid.Sus/TPK/2016/PT.DKI Jo Putusan Pengadilan Tindak Pidana Korupsi Pada Pengadilan Negeri Jakarta Pusat Nomor: 67/Pid.Sus/TPK/2015/PN.Jkt.Pst ini telah melanggar Kode Etik Dan Pedoman Perilaku Hakim sebagaimana yang tertuang didalam Keputsan Bersama Ketua Mahkamah Agung RI Nomor: 047/KMA/SKB/IV/2009 dan Ketua Komisi Yudisial RI Nomor: 02/SKB/P.KY/IV/2009 tentang Kode Etik Dan Pedoman Perilaku Hakim, khususnya ketentuan ke 5 tentang "Berintegritas Tinggi" dan ketentuan ke 10 tentang "Bersikap Profesional."

Telah terjadi pelanggaran terhadap hukum acara pidana (KUHAP) yang seharusnya merupakan panduan bagi hakim dalam memeriksa dan mengadili suatu perkara pidana dan telah dilakukan pula penerapan hukum yang keliru oleh hakim dalam perkara ini. Pelanggaran terhadap hukum acara dan penerapan hukum yang keliru ini mencerminkan dengan jelas sekali bahwa hakim yang memeriksa dan memutus perkara atas nama Barnabas Suebu ini tidak melaksanakan ketentuan Kode Etik Dan Pedoman Perilaku Hakim dalam pengaturan ke 5 bahwa hakim harus berintegritas tinggi dan ketentuan ke 10 yang menetukan bahwa hakim harus bersikap profesional. Pelanggaran atas hukum acara dan penerapan hukum yang keliru ini jelas sekali tidak sejalan dengan prinsip bahwa sebagai seorang professional hakim itu harus memiliki kompetensi, pengetahuan hukum, keterampilan. Kompetensi professional seorang hakim itu harus kelihatan dan terbukti dalam pelaksanaan tugas dan fungsi yudisialnya. ${ }^{22}$

Pelanggaran yang telah dilakukan oleh hakim Pengadilan Tinggi DKI dalam kasus Barnabas Suebu ini juga dapat dikategorikan sebagai pelanggaran

${ }^{22}$ United Nations Office on Drugs and Crime, Commentary On the Bangalore Principles Of Judicial Conduct, September 2007 Hlm.129 
atas Kode Etik Dan Pedoman Perilaku Hakim yang sekaligus juga merupakan pelanggaran atas Hukum Acara sebagaimana yang dimaksudkan dalam Peraturan Bersama (PB) Ketua Mahkamah Agung RI Dan Ketua Komisi Yudisial RI No: 02/PB/MA/IX/2012 Dan No:02/PB/P.KY/09/2012 Tentang Panduan Penegakan Kode Etik Dan Pedoman Perilaku Hakim. Dalam Pasal 17 (1) Peraturan Bersama ini ditentukan bahwa "dalam hal Komisi Yudisial menerima laporan dugaan pelanggaran kode etik yang juga merupakan pelanggaran hukum acara, Komisi Yudisial dapat mengusulkan kepada Mahkamah Agung untuk ditindak lanjuti.” Selanjutnya dalam Pasal 18 (4) Peraturan Bersama ini dikatakan bahwa "pelanggaran terhadap Pasal 12 dan Pasal 14 dapat dikategorikan pelanggaran ringan, sedang atau berat, tergantung dari dampak yang ditimbulkannya."

Jadi secara hukum ada dasar yang sangat kuat sekali bagi Sdr. Barnabas Suebu untuk membuat laporan kepada Komisi Yudisial terkait dengan adanya dugaan tentang telah terjadinya pelanggaran, yang menurut penulis termasuk kategori pelanggaran berat, seperti yang diatur dalam Pasal 17 dan Pasal 18 (4) Peraturan Bersama Ketua Mahkamah Agung Dan Ketua Komisi Yudisial tersebut tersebut. 


\section{DAFTAR PUSTAKA}

\section{BUKU}

American Bar Association, ABA Model Code Of Judicial Conduct, ABA, February 2007

Aronson, Robert H., Professional Responsibility In a Nutshell, West Publishing, St. Paul, 1991

Gray, Cynthia, The Line Between Legal Error and Judicial Misconduct: Balancing Judicial Independence and Accountability, Hostra Law Review, Volume 32 Issue 4, 2004

IBA, The International Bar Association Judicial Integrity Initiative: Judicial Systems and Corruption, 2016.

Komsi Yudisial RI, Optimalisasi Kewenangan Komisi Yudisial Dalam Mewujudkan Hakim Berintegritas, Sekretariat Jenderal Komisi Yudisial RI, Jakarta, 2016

Komisi Yudisial RI, Menggagas Peradilan Etik Di Indonesia, Sekreteriat Jenderal Komisi Judisial RI, Jakarta, 2015

Manao, Disiplin F dan Elpah, Dani (eds), Hakim: Antara Pengaturan Dan Implementasinya, Yayasan Pustaka Obor Indonesia, Jakarta, 2018

New Mexico Judicial Education Center, New Mexico Judicial Ethics Handbook, Albuquerque, 2011

Ratner, Morris A., Judical Ethical Integrity: Challenges and Solutions, Hastings Int'L \& Comp. L. Rev, Vol.39:1, 2016 2004

Sajo, Andras (ed), Judicial Integrity, Martinus Nijhoff Publishers, Leiden,

Soeharno, Jonathan, Is Judicial Integrity a Norm? An Inquiry into the Concept of Judicial Integrity in England and the Netherlands, Utrecht Law Review, Volume 3, Issue 1 (June), 2007

UNDP, A Transparent And Accountable Judiciary To Deliver Justice For All, UNDP, 2016

United Nations Office on Drugs and Crime, Commentary On The Bangalore Principles Of Judicial Conduct, 2007

Vago, Steven, Law and Society, Prentice Hall, New Jersey, 2003 


\section{PERATURAN PERUNDANG-UNDANGAN}

Peraturan Mahkamah Agung RI Nomor 8 Tahun 2016 Tentang Pengawasan Dan Pembinaan Atasan Langsung Di Lingkungan Mahkamah Agung Dan Badan Peradilan Di Lingkungan Mahkamh Agung Dan Badan Peradilan Di Bawahnya

Keputusan Bersama Ketua Mahkamah Agung RI Dan Ketua Komisi Yudisial RI Nomor: 047/KMA/SKB/IV/2009 Dan 02/SKB/P.KY/IV/2009 Tentang Kode Etik Dan Pedoman Perilaku Hakim

Peraturan Bersama Ketua Mahkamah Agung RI Dan Ketua Komisi Yudisial RI No.02/PB MA/IX/2012 Dan No.02/PB/P.KY/09/ 2012 Tentang Panduan Penegakan Kode Etik Dan Pedoman Perilaku Hakim 